Language in Society 28, 355-365. Printed in the United States of America

\title{
The expression of evidentiality in French-English bilingual discourse
}

\author{
R U T H K I N G \\ Dept. of Languages, Literatures \& Linguistics, York University \\ Toronto, Ontario M3J 1P3, Canada \\ rking@yorku.ca \\ TERR Y NADA S D I \\ Dept. of Modern Languages \& Cultural Studies, University of Alberta \\ Edmonton, Alberta T6G 2E1, Canada \\ terry.nadasdi@ualberta.ca
}

A B S T R AC T

This study, drawing on data from a large sociolinguistic interview corpus for three Acadian communities of Atlantic Canada, concerns codeswitches involving verbs of opinion or belief (e.g. guess, think, imagine, believe) in French-English bilingual discourse. The codeswitch itself serves to underscore the speaker's stance as to the truth of the proposition - and, in some cases, to indicate a degree of uncertainty not nuanced by corresponding French language forms. Variation in usage is related to intensity of language contact at the levels of the community and of the individual. (Codeswitching, discourse analysis, evidentiality, quantitative sociolinguistics, Canada, Acadian, French)*

Most recent research on codeswitching has been conducted from one of two perspectives: grammatical or interactional. The search for grammatical constraints on intrasentential codeswitching exemplifies the grammatical perspective (e.g. Poplack 1980, DiSciullo et al. 1986, Poplack et al. 1989, Myers-Scotton 1993, Belazi et al. 1994, Mahootian \& Santorini 1996), while the study of the social meaning of particular codeswitches exemplifies the interactional perspective (e.g. Gumperz 1982, Heller 1982, 1988, 1994). The present article concentrates instead on the role of codeswitching in the organization of discourse; specifically, it is concerned with how codeswitching figures in the expression of evidentiality in French-English bilingual discourse. Following Auer 1995, we argue that codeswitching can be analyzed at the level of discourse, relatively independently of any grammatical properties of codeswitching or of the immediate social context in which it is embedded. We do turn, however, to consideration of the sociolinguistic situation in order to explain inter- and intra-community variation.

(C) 1999 Cambridge University Press 0047-4045/99 \$9.50 
THE CORPUS

The present study is concerned with language use in three Acadian communities of Atlantic Canada, two in the province of Prince Edward Island (PEI) (AbramVillage and Saint-Louis), and one in Newfoundland (L'Anse-à-Canards). All are small fishing villages with fewer than five hundred residents. Although the grammars of these three varieties are the same for those linguistic features relevant for our study, the relative prestige of French differs in the three communities, as does the degree of contact with English.

L'Anse-à-Canards is situated in an isolated part of Newfoundland where there was little contact with English before World War II. ${ }^{1}$ Until quite recently, education in French has been negligible. Elsewhere (King 1989, King \& Nadasdi 1997) we have shown that Newfoundland French is one of the most conservative Acadian varieties as regards influence from English or from other varieties of French, including the standard. The two PEI varieties under discussion have been in closer contact with English, for a longer period, but there are striking differences between the two communities. Abram-Village is situated in a small enclave, the Evangéline region, where French is the majority language locally, although it is in a minority position in the province as a whole. There is strong institutional support for French, and thus our sample includes speakers with some control of the standard as well as of the local variety. Saint-Louis, by contrast, is surrounded by English-speaking villages, and there is little institutional support for French. Not surprisingly, lack of transmission of the language to the young is a serious problem faced by the community. Speakers of Saint-Louis French have had more exposure to English, but less exposure to Standard French, than their counterparts in Abram-Village.

A sociolinguistic interview corpus for twenty-four Abram-Village residents and twenty Saint-Louis residents, comprising a total of just over 800,000 words, provides the main data for our study; a subsample of our L'Anse-à-Canards corpus, comprising interview data for eight residents and consisting of just over 100,000 words, was used for comparative purposes.

SWITCHED FORMS

The data in exx. 1-3 come from our interview corpus. ${ }^{2}$ In all cases, the matrix language is French:

(1) I guess qu'on est pas mal tout pareil. (19.2A.255, Abram-Village) 'I guess that we are just about all equal.'

(2) I think j'ai plus peur des chenilles qu'une serpent. ${ }^{3}$ (30.2A.47, Saint-Louis) 'I think (that) I'm more afraid of caterpillars than a snake.'

(3) I imagine qu'il y en a qui l'avont encore. (29.1B.269, Saint-Louis) 'I imagine that there are some who still have it.'

In the PEI corpora, one finds codeswitches like I guess, I imagine, I think, I bet, and $I$ ' $m$ sure with French that-clause complements. Such tokens all involve a $1 \mathrm{sg}$. 
pronoun; i.e., one does not find examples like 4 , with a 1 pl. pronoun, or 5 , with a lexical NP as subject:

(4) *We guess qu'on est pas mal tout pareil.

'We guess that we are just about all equal.'

(5) *Marie doesn't know quoi ce qu'a arrivé.

'Marie doesn't know what happened.'

In addition to the matrix clause use of English codeswitches, there is also widespread use of emblematic, or tag, switching, involving I think, I guess, I imagine, etc. at the "edges" of sentences (as in 6-8). We also find sentential codeswitching (9-10):

(6) Ils avont pas mal de la misère, I guess. (01.1B.407, Abram-Village) 'They are having a hard time, I guess.'

(7) J'étions une quarantaine, I suppose, une quarantaine. (30.1A.108, Saint-Louis) 'There were about forty of us, I suppose, about forty.'

(8) C'est sept ou huit heures, je sais pas, huit heures, I imagine. (33.1B.810, Saint-Louis) 'It's seven or eight hours, I don't know, eight hours, I imagine.'

(9) A: Les Français alentour d'icitte s'accordont bien? '(Do) the French around here get along well?'

B: Bien, I guess so. 'Well, I guess so.'

A: Ils travaillont ti ensemble? 'Do they work together?'

B: Oui, oui. (27.1B.208, Saint-Louis) 'Yes, yes.'

(10) A: Les traditions de la communauté comme la râpure puis les fricots puis toute ça, c'est ti de quoi qui va rester avec les jeunes?

'Community traditions like rapure and fricot and all that, is that something that is going to stay with young people?'

B: Ahoui! Je crois quasiment, je crois quasiment que oui. I think so. Je sais pas. (19.2B.273, Abram-Village)

'Oh yes! I believe pretty much so, I believe pretty much so, yes. I think so. I don't know (for sure).'

While our primary focus will be on intrasentential and emblematic codeswitches, it is worth noting that there are no striking differences in verb choice in singleclause utterances.

English verbs employed in codeswitches are the following, in order of frequency: guess, think, don't know, don't think, imagine, believe, suppose, be sure, bet, and can't see.

We do not find other high-frequency English verbs, such as say, tell, ask, remember, show, or explain - and this, we argue, is not accidental.

THE EXPRESSION OF EVIDENTIALITY

Regardless of syntactic position, we find that the choice of verb is semantically constrained: Codeswitches occur with a particular class of evidentials, namely verbs of opinion or belief. No such codeswitches are found with other classes of 
verbs which take that-clause complements in English (cf. Partee 1973), such as verbs of communication (say, tell, explain), verbs of inference (prove, show, discover), or emotives (be sad, be glad, hate). Thus, we do not find examples such as I said que or I showed que.

Close analysis of the surrounding text leads us to suggest that, in many cases, the codeswitches serve to mitigate the speaker's relationship to the proposition expressed in the embedded clause. In 11, the local interviewer asks the informant, a middle-aged Saint-Louis male, about his father's seeing the ghost of his first wife:

(11) A: Ç’a ti ienque arrivé une fois ou - ? 'Did that happen only once or - ?'

B: Bien ... as far as I know, oui.

'Well ... as far as I know, yes.'

A: Mmhmm. Il était ti marié là dans ce temps là ... à sa deuxième femme?

'Mmhmm. Was he married then ... to his second wife?'

B: I guess qu'il était marié avec la deuxième femme. I think qu'il était marié then. (39.1B.532-534, Saint-Louis)

'I guess he was married to the second wife. I think he was married then.'

The interviewer asks if it happened just once. The informant responds, in English, as far as I know. The interviewer then asks whether the informant's father was married to his second wife at the time. The informant responds that he guesses his father was, that he thinks he was remarried then. Here, uncertainty as to the truth of the proposition is highlighted by the switch to English.

In 12, however, the informant's belief in the truth of the proposition expressed in the embedded clause is emphasized by the codeswitch:

(12) A: Moi, je sais qu'on peut avoir de la fun pareil parce que j'en ai l'expérience parce que, je disais, comment j'avais fait ma folle puis chanté puis toute ça, puis je prends pas une drink! Ça fait, toujours trois ans, at least. Bien avant, c'est pas à-cause j'en prenais beaucoup, j'en prenais justement une petite social drink. Bien je m'ai, je m'ai juste décidé, ça, pour, des certaines raisons, oui, que j'allais juste jamais en toucher back de ma vie.

'Me, I know you can have fun anyway because I've had the experience, because, like I was saying, how I played the fool and sang and all that, and I don't have a drink! That's three years, at least. Well before, it wasn't that I drank a lot, I used to have a little social drink. Well, I just decided, that, for, certain reasons, yes, I was never going to touch any again for the rest of my life.'

B: Mmhmm.

A: Puis, je touche pas à un petit wine, rien, rien.

'And, I don't (even) have a little wine, nothing, nothing.'

B: Non.

A: Puis des fois, bien j'ai assez folle, ah, tu sais, je m'enjoye assez, je vas à une danse, je danse assez, bien I'm sure qu'il y en a qui disont "Tu bois en cachette." Ils voulont pas me croire, bien, c'est pas vrai. (06.2B.186-190, Abram-Village)

'And sometimes, when I'm acting the fool, ah, you know, I'm really enjoying myself, I go to a dance, I dance a lot, well I'm sure that some say "You drink in secret." They don't want to believe me, well, it's not true.'

In this case, a middle-aged Abram-Village woman, well-known in the community as the life of the party, declares that she no longer takes a drink, ever. But, she says, she's sure there are some who think she drinks in secret, although she has no 
evidence to that effect. The two cases are linked, then, in that opinions or beliefs are involved, as is degree of uncertainty.

It turns out that limitations on the various meanings are conveyed by the English verbs in question. For instance, no examples were found in which guess might be paraphrased as 'predict', as in 13 , or in which think might be paraphrased as 'reflect', as in 14:

(13) *I guessed que ça serait un problème. 'I guessed that it would be a problem.'

(14) *I think about ça souvent. ${ }^{4}$ 'I think about that often.'

These lacunae lend support to the present analysis of the discursive function of the codeswitches; that is, they are used to underscore a speaker's personal opinion about something, or to indicate one's uncertainty as to the veracity of a statement. But is codeswitching the only means for indicating this kind of uncertainty? To explore this question, we turn to data from five heavy codeswitchers, and compare their use of I guess and I think with what might be considered French language equivalents. In so doing, we address the question of whether these forms are true equivalents.

FRENCH-LANGUAGE EQUIVALENTS OF ENGLISH CODESWITCHES

I guess, as used in 15-16, is the indicator par excellence of uncertainty, especially for those speakers who stand out in terms of the sheer number of codeswitches contained within their interviews - both codeswitches relating to belief or opinion, and codeswitches in general.

(15) I guess la tide était trop haute. (30.2B.119, Saint-Louis) 'I guess the tide was too high.'

(16) I guess je devrais parler en français. (29.1B.376, Saint-Louis) 'I guess I should speak French.'

Here, and indeed in the vast majority of such sentences, I guess indicates to the listener that the speaker is taking a stance on the veracity of the following proposition, but she is extremely uncertain. Can this same degree of uncertainty be rendered by a French equivalent? Potential candidates for French equivalents of I guess include je crois (que) 'I believe (that)', je pense (que) 'I think (that)', me semble (que) '(it) seems to me', à moi 'to me', j'imagine (que) 'I imagine (that)', and je suppose (que) 'I suppose (that)' ${ }^{5}$ While the first four forms certainly allow a speaker to take a stance on the veracity of a statement or event, the degree of certainty indicated is actually quite strong. They are used when speakers want to indicate that they are fairly certain that a proposition is or is not true: they indicate a degree of certainty greater than does I guess. One might argue that j'imagine indicates a high degree of uncertainty, similar to that indicated by I guess; however, this form is not used by our heavy codeswitchers. Likewise, je suppose is 
RUTH KING AND TERRY NADASDI

TABLE 1. Distribution of I think and French-language equivalents, 5 selected speakers.

\begin{tabular}{lcc}
\hline \hline Verb & $\begin{array}{c}\text { Accomplished } \\
\text { events }\end{array}$ & $\begin{array}{c}\text { Unaccomplished } \\
\text { events }\end{array}$ \\
\hline I think (que) & $12(20 \%)$ & $48(80 \%)$ \\
je crois (que) & $82(54 \%)$ & $66(46 \%)$ \\
me semble (que) & $51(51 \%)$ & $49(49 \%)$ \\
je pense (que) & 0 & 0 \\
\hline \hline
\end{tabular}

absent from our corpus: we find only the deontic supposé, as in J'étais supposé le faire 'I was supposed to do it.' It would appear, then, that I guess fulfills an intermediate role; it indicates that the speaker does in fact take a stance as to the veracity of a proposition - a stance that is extremely weak, much weaker than any potential French language equivalent. Thus, switching to I guess enables the speaker to indicate a degree of uncertainty previously not nuanced in the language.

What about forms like I think? Close examination of the data indicates that, unlike the case for I guess, there is no strong evidence that a switch to I think indicates a greater degree of uncertainty than French language equivalent forms like je pense que 'I think that', je crois (que) 'I think (that)', je trouve (que) 'I find (that)', je dirais (que) 'I would say (that)', me semble (que) '(it) seems to me (that)', or à moi 'to me'. We note that je pense seems to be absent from the heavy codeswitchers' inventory of terms used to indicate uncertainty. However, the other forms do occur, and they seem to be interchangeable with I think. For example, the meaning of the main clause of 17 a seems to be the same as that of $17 \mathrm{~b}$ :

(17) a. I think que c'est ça qu'arrive. 'I think that's what happens.'

b. Je crois que c'est ça qu'arrive. 'I believe that's what happens.'

There may, however, still be reason to believe that these are not absolute equivalents. The data in Table 1 compare propositions which follow I think and its French language equivalents, and which involve cases where a speaker takes a stance on the veracity of a statement.

The propositions involved fall into two basic categories: (a) events/facts accomplished in the past (exx. 18a-b), and (b) unaccomplished events that are hypothetical or ongoing (exx. 19a-b).

(18) Accomplished events/facts

a. Je crois qu'elle avait sixty-five. (30.2B.286, Saint-Louis)

'I believe she was sixty-five.' 
b. Elle m'avait demandé pour un hanger une journée puis I think que j'ai été lui quérir des clothes pins. (29.1B.245, Saint-Louis)

'She had asked me for a hanger one day and I think I went to look for some clothes pins for her.'

(19) Unaccomplished, current or hypothetical events/facts

a. I don't think que je pourrais vivre comme une femme qui serait amarrée à la maison. (30.3B.134-135, Saint-Louis)

'I don't think that I could live as a woman who would be tied to the house.'

b. Me semble ça devrait être un homme qui serait un prêtre à cause le bon Dieu était un homme. (31.1A.39, Saint-Louis)

'It seems to me (that) it should be a man who should be a priest since God was a man.'

Table 1 provides results for how often a speaker's degree of uncertainty is indicated by codeswitches with I think, and how often it is indicated by French language equivalents for both categories of information. These numbers include all types of codeswitches: those occurring in matrix clauses, those in single-clause utterances, and those at the "edges" of utterances.

These results reveal that, while all forms can be used to indicate a speaker's opinion relative to the veracity of both accomplished events and unaccomplished events, I think is used primarily for the latter category of information. By contrast, the French language equivalent forms are evenly distributed across accomplished and unaccomplished events. In other words, the English form is used first and foremost to take a stance on information the veracity of which, by its very nature, is relatively uncertain. It would appear, then, that when one uses a French language equivalent, one's confidence in the veracity of a statement is still appreciably greater than when one introduces a stance on information by an English codeswitch.

Thus, while I think and its French language alternants can be used in the same context, it is not obvious that they are absolute equivalents. A codeswitch to $I$ think underscores a speaker's uncertainty vis-à-vis a proposition; it indicates to the listener that the uncertainty is greater. In other words, whenever a French equivalent is used, the speaker could have used an English codeswitch to underscore the uncertainty. Ex. 10 above, repeated here, shows this clearly:

(20) A: Les traditions de la communauté comme la râpure puis les fricots puis toute ça, c'est ti de quoi qui va rester avec les jeunes?

'Community traditions like râpure and fricot and all that, is that something that is going to stay with young people?'

B: Ahoui! Je crois quasiment, je crois quasiment que oui. Ithink so. Je sais pas. (19.2B.273, Abram-Village)

'Oh yes! I believe pretty much so, I believe pretty much so, yes. I think so. I don't know (for sure).'

Here we see that B comments on whether the old traditions, in this case traditional Acadian dishes, will be retained by the young. He comments in French that "he believes, pretty much so." Then he says, I think so. Je sais pas. We interpret this as a decrescendo from fairly certain ( je crois) to relative uncertainty (I think so), to absolute uncertainty ( $j e$ sais pas). 
RUTH KING AND TERRY NADASDI

TABLE 2. English verbs used in codeswitches.

\begin{tabular}{|c|c|c|c|c|c|c|}
\hline \multirow[b]{2}{*}{ Verb } & \multicolumn{2}{|c|}{ Saint-Louis } & \multicolumn{2}{|c|}{ Abram-Village } & \multicolumn{2}{|c|}{ L'Anse-à-Canards } \\
\hline & Matrix & Elsewhere & Matrix & Elsewhere & Matrix & Elsewhere \\
\hline am sure & 3 & 0 & 1 & 0 & 0 & 0 \\
\hline believe & 4 & 2 & 0 & 0 & 0 & 0 \\
\hline bet & 2 & 2 & 0 & 0 & 0 & 0 \\
\hline can't see & 1 & 0 & 0 & 0 & 0 & 0 \\
\hline doubt & 0 & 0 & 0 & 1 & 0 & 0 \\
\hline guess & 98 & 85 & 23 & 97 & 17 & 69 \\
\hline imagine & 8 & 8 & 0 & 0 & 0 & 0 \\
\hline know (don't know) & $1(0)$ & $3(47)$ & 0 & $2(4)$ & 0 & 0 \\
\hline suppose & 0 & 6 & 0 & 0 & 0 & 0 \\
\hline think (don't think) & $43(4)$ & 47 (19) & 0 & $5(3)$ & 0 & 0 \\
\hline
\end{tabular}

\section{I S C U S S I O N}

Table 2 presents the full set of English opinion-related verbs that occurred in matrix clauses and in other contexts; here we have combined our "edge" category with our "single-clause utterance" category. ${ }^{6}$

Looking at all three corpora, we find that the most frequently occurring English verb is guess - which, as noted above, is the indicator par excellence of uncertainty about information. Indeed, of those speakers who exhibited the phenomenon, more than 85 percent had guess (as their only English verb, or as one of their verbs) in matrix clauses. The pervasiveness of I guess suggests that, in communities where its use is widespread, it was the first English form used to underscore a speaker's uncertainty. As previously suggested, it appears that the switch to I guess came on the scene to allow the speaker to indicate a nuance of uncertainty that was not previously distinguished. Developments of this type certainly have precedents in language contact situations. For example, Poplack et al. 1988 suggest that the borrowing of cute in Quebec French originated from a desire to nuance between different registers; Nadasdi 1991 also gives examples of this type for Quebec French. However, the case presented here is unique, inasmuch as it is not just the English form that allows the speaker to indicate a greater nuance in meaning, but the actual codeswitch itself, especially with codeswitches involving forms other than I guess. ${ }^{7}$

It is arguable that the greater degree of uncertainty which initially accompanied the switch to I guess was later associated with all switches to English that involve stances on veracity. The data also suggest that the English codeswitches began (on the edges of utterances) with speakers wanting to take a weak stance vis-à-vis the veracity of a statement or occurrence. I guess may well have been the 
first form so used (indeed, it is the only one used by L'Anse-à-Canards speakers), followed by I think and others - but only to indicate uncertainty, not personal opinion, as in I think que l'église est mortellement belle 'I think the church is really beautiful' (27.1 A.255, Saint-Louis). The latter development, we would argue, is more recent.

Intensive language contact seems to be a prerequisite to the kind of discursive behavior described here; not surprisingly, then, it is not reported for Quebec French. Elsewhere in Canada, where French is a minority language, we do find evidence of substantial use of English language discourse markers. Thus Mougeon and Hébrard 1975 report that English anyway, well, you know etc. are associated with working-class Ontario French, in particular that of speakers who speak both English and French on a regular basis; Roy 1979 makes a similar observation for use of but and so by working-class speakers of Acadian French in Moncton, New Brunswick.

The data in Table 2 show striking intercommunity differences, which also suggest that intensity of contact with English is an important factor. As noted above, L'Anse-à-Canards French, spoken in Newfoundland, has had the least contact with English, followed by the French of Abram-Village, PEI. In SaintLouis, the other PEI community, contact with English is most intense. Although all three varieties clearly are partial to guess, we note the lack of occurrence of other English verbs in the L'Anse-à-Canards corpus. Abram-Village appears more "advanced" than L'Anse-à-Canards in this regard, but less so than Saint-Louis.

The table masks a certain amount of variation, however, in that PARTICULAR Saint-Louis speakers are the heaviest codeswitchers, in terms of both number of switches and variety of English verbs used. In our corpus, the Saint-Louis women (married with children) stand out as star codeswitchers, and as most advanced in the use of this particular type of switch. The data for Table 1, for instance, come from five of these women. These Saint-Louis women's use of English is greater than that of other members of the sample. Most do not work outside the home, and if they do, they work at jobs that are conducted in English. Male Saint-Louis residents, on the other hand, have a far greater tendency to work at unskilled labor with other French-speaking men. Women bear the primary responsibility for childrearing and are largely raising English-speaking children. Both participant observation and self-report data indicate that, although the Saint-Louis women are clearly fluent speakers of the Acadian variety, a larger proportion of their lives is led in English than is the case for any other speakers in the three corpora. Seen in this light, their status as star codeswitchers is not surprising. The situation of these Saint-Louis women reminds us of that of some of the Francophone women studied by Heller \& Lévy 1992 in Ontario, Canada - women for whom English plays a major role in the workplace and in the home. Indeed, one of these women expressed her ethnic identity as follows (Monica Heller, p.c.): Je suis canadiennefrançaise, I guess. 


\section{ONCLUSION}

The present study has attempted to shed light on the discursive function of codeswitching in several varieties of Acadian French. Our approach has allowed us to identify the role of English codeswitching in indicating a bilingual's uncertainty vis-à-vis certain types of propositions. We have suggested that the English form first used in this manner was I guess, arguing that the nuance in meaning that it provided was a motivating force for its initial use in the varieties of French spoken in Prince Edward Island and Newfoundland. We have also suggested that the degree of uncertainty that accompanied switching to this form has become associated with all semantically related codeswitches to English in two of these varieties. Finally, the intensity of language contact at the level of both community and individual is related to how advanced such usage has become.

\section{NOTES}

* This research was supported in part by Social Sciences and Humanities Research Council of Canada Standard Research Grants \#410-92-1021 (King) and \#410-98-1039 (King \& Nadasdi). We wish to thank Gary Butler for discussing some of the data with us, and Susan Ehrlich and Monica Heller for suggesting some important references. We also thank Pierrette Thibault for comments that led us to clarify some of our arguments. An earlier version of this article was presented at NWAVE-25, Las Vegas (October 1996).

${ }^{1}$ See King 1989, 1994, King \& Nadasdi 1996 for more discussion of the sociolinguistic situation in the three communities.

${ }^{2}$ All data are given with the speaker number, tape, line number of the written transcript, and community.

${ }^{3}$ As in other varieties of Canadian French (cf. G. Sankoff 1980, Martineau 1985), presence of the que complementizer is variable in Acadian French. We have not found quantitative evidence of a relationship of codeswitching to its presence or absence.

${ }^{4}$ Both Prince Edward Island varieties have borrowed about.

${ }^{5}$ Forms like peut-être (que) 'maybe (that)' also allow the speaker to take a stance on veracity; however, we limit the comparison to matrix-clause verbs, since the inclusion of modal expressions is beyond the scope of the study.

${ }^{6}$ A total of approximately 600 tokens involved switches to English. This frequency may strike one as low; indeed, quantitative analysis of large corpora is necessary to identify such data as constituting a pattern. However, it must be kept in mind that the linguistic expression of attitudes arising through opinion or belief is not particularly frequent in discourse: Chafe (1986:266) reports just 3.6 occurrences per 1000 words in conversational written English, giving us a rough basis for comparison with usage in our oral corpus. Given that our corpus is approximately 900,000 words, our English data amount to, relatively speaking, about one-fifth of the proportion found by Chafe. If one considers that our consultants vary in terms of the degree to which they employ English switches, and that almost everyone has SOME examples of je crois, me semble etc., that can be characterized as opinion-giving, then our results are not unexpected.

${ }^{7}$ Maschler 1994 also makes this second point regarding the use of English discourse markers (e.g., so, but, you know) in English-Hebrew codeswitching; i.e., the verbal activity is marked not just by the presence of a discourse marker, but also by the act of codeswitching.

\section{REFERENCES}

Auer, Peter (1995). The pragmatics of code-switching: A sequential approach. In Leslie Milroy \& Pieter Muysken (eds.), One speaker, two languages: Cross-disciplinary perspectives on codeswitching, 115-35. Cambridge \& New York: Cambridge University Press. 


\section{EVIDENTIALITY IN FRENCH-ENGLISH BILINGUAL DISCOURSE}

Belazi, Hedi; Rubin, Edward; \& Toribio, Jacqueline (1994). Codeswitching and X-bar theory: The functional head constraint. Linguistic Inquiry 25:221-37.

Chafe, Wallace (1986). Evidentiality in English conversation and in academic writing. In Wallace Chafe \& Joanna Nichols (eds.), Evidentiality: The linguistic encoding of epistemology (Advances in discourse processes, 20), 261-72. Norwood, NJ: Ablex.

Di Sciullo, Anne-Marie; Muysken, Peter; \& Singh, Rajendra (1986). Government and codeswitching. Journal of Linguistics 22:1-24.

Gumperz, John (1982). Discourse strategies. Cambridge \& New York: Cambridge University Press.

Heller, Monica (1982). Negotiations of language choice in Montreal. In John Gumperz (ed.), Language and social identity, 108-118. Cambridge \& New York: Cambridge University Press.

(1988), ed. Code-switching: Anthropological and sociolinguistic perspectives. Berlin: Mouton de Gruyter.

(1994). Crosswords: Language, education and ethnicity in French Ontario. Berlin: Mouton de Gruyter.

43.

King, Ruth (1989). Le français terreneuvien: Aperçu général. In Raymond Mougeon \& Édouard Béniak (eds.), Le français canadien hors Québec: Aperçu sociolinguistique, 227-44. Québec: Presses de l'Université Laval.

(1994). Subject-verb agreement in Newfoundland French. Language Variation and Change 23:239-53.

\& Nadasdi, Terry (1996). Sorting out morphosyntactic variation in Acadian French: The importance of the linguistic marketplace. In Sociolinguistic variation: Data, theory and method (Selected papers from NWAVE23, Stanford), 113-28. Stanford, CA: CSLI.

(1997). Left dislocation, number marking and Canadian French. Probus 9:267-84.

Mahootian, Shahrzad, \& Santorini, Beatrice (1996). Code switching and the complement/adjunct distinction: A reply to Belazi, Rubin and Toribio. Linguistic Inquiry 27:464-79.

Martineau, France (1985). L'élision variable de (que) dans le parler de Ottawa-Hull. M.A. thesis, University of Ottawa.

Maschler, Yael (1994). Metalanguaging and discourse markers in bilingual conversation. Language in Society 23:325-66.

Mougeon, Raymond, \& Hébrard, Pierre (1975). Aspects de l'assimilation linguistique dans une communauté francophone de l'Ontario. Working Papers on Bilingualism (Ontario Institute for Studies in Education) 5:1-38.

Myers-Scotton, Carol (1993). Duelling languages: Grammatical structure in codeswitching. Oxford \& New York: Oxford University Press.

Nadasdi, Terry (1991). Divergence sémantique des anglicismes au Québec. Revue Québécoise de Linguistique Théorique et Appliquée 10:3.173-87.

Partee, Barbara Hall (1973). The semantics of belief-sentences. In Jaakko Hintikka et al. (eds.), Approaches to natural language, 309-36. Dordrecht: Reidel.

Poplack, Shana (1980). "Sometimes I'll start a sentence in Spanish Y TERMINO EN ESPAÑoL": Toward a typology of codeswitching. Linguistics 18:581-618.

; Sankoff, David; \& Miller, Christopher (1988). The social correlates and linguistic processes of lexical borrowing and assimilation. Linguistics 26:47-104

; Wheeler, Susan; \& Westwood, Anneli (1989). Distinguishing language contact phenomena: Evidence from Finnish-English bilingualism. World Englishes 8:389-406.

Roy, Marie-Marthe (1979). Les conjonctions anglaises "but" et "so" dans le français de Moncton: Une étude sociolinguistique de changements linguistiques provoqués par une situation de contact. M.A. thesis, Université du Québec à Montréal.

Sankoff, Gillian (1980). A quantitative paradigm for the study of communicative competence. In her The social life of language, 47-79. Philadelphia: University of Pennsylvania Press. 